\title{
The Application Of Liquid Fertilizer Made Of Traditional Market Organic Wastes On Growth Of Setaria Grass (Setaria splendida Stapf)
}

\author{
Eko Hendarto $^{1, *}$ and Suwarno ${ }^{1}$ \\ ${ }^{1}$ Faculty Of Animal Husbandry, Jenderal Soedirman University, Purwokerto - Indonesia
}

\begin{abstract}
There are hugh amount of traditional market organic wastes that may polute the environment. In general, the wastes are utilized for compost making and liquid fertilizer as well for plant. The use of liquid fertilizer from organic wastes of traditional markets opens up opportunities for misplaced cultivation of Setaria grass (Setaria splendida Stapf), which is required by ruminant farms. This research was conducted to evaluate the best mixture of water to the fertilizer in term of its effectiveness on the variables and experimental method using Completely Randomized Design. The treatments were: 6 doses of mixtures namely $0,10,20,30,40$ and 50 liters of water, each of which was mixed with 10 liters of liquid fertilizer. The variables measured were the height, the numbers of tillers, the numbers of leaves, and canopy. The results of the study showed that the doses of water in the fertilizer did not indicate any significant differences $(\mathrm{P}>0.05)$ on all variables being studied, however, the linear equation showed that greater concentrations of water in the fertilizer tended to decrease the growth of Setaria grass. Suggested use of water on the liquid fertilizer mixture should be not greater than $301-101$ fertilizer.
\end{abstract}

\section{Introduction}

In all of the cities, traditional markets produce large amount of wastes that may pollute the environment, one of which is organic wastes. However, the waste can be used to support human life by converting it to become composts. Via the technology of processing, the wastes produce liquid fertilizer that can be used to support the growth of plants. One of the advantages of using liquid organic fertilizers into plants is the easily absorbed nutrients in the fertilizers by the soil that can readily be utilized by the plants.

The product of forage plants is forage that can be used to feed the ruminants, therefore, it functions to support the development of ruminant farmings [1]. As a feed, the forage consists of leaves and twights, which is the most nutritious parts of the forage plants [2]. Setaria grass is famous to the livestock farmers as the most preferred feedstuff by the ruminants.

Liquid organic fertilizers generally have low concentration of chemical compounds with fairly good nutrient content to fulfill the plant requirement. If there is an excessive amount of the fertilizer in the soil, the plants can easily control its absorption [3]. The mentioned characteristics of liquid organic fertilizers is also owned by the traditional market-waste organic fertilizer, in the other side, the making or processing the wastes into the fertilizer can reduce the pollution and prolong the utilization of WEP (Waste End Processing) site, due to the reduced amount of wastes being dumped into the site. The waste processing also opens the opportunity to decrease unemployment. A traditional market can produce the daily wastes up to a value greater than $100 \mathrm{~m}^{3}$ [4], therefore, the potent to produce the liquid fertilizer is huge in order to guarantee the longterm availability of the liquid organic fertilizers made of traditional market wastes.

In common, liquid fertilizer is only applied for ornamental plants such as orchids, palms, roses, jasmines, and so on. However, it can also be used for grasses to widen it utilization in the livestock farmings, in an effort to support the environmental awareness activities. The utilization of organic fertilizers can improve the soil quality for plant growth, therefore, increase its productivity. The productivity aspects that can be on served include plant height, the numbers of tillers and leaves, and the width of canopy.

The increase of forage plant productivity one of which is via fertilization management of Setaria finally increases the animal growth and products [5]. In relation to the ideas mentioned above, a study concerning the effects of the utilization of traditional-market-waste organic fertilizer on the growth of Setaria (Setaria splendida) was conducted to support the development of ruminant farming in order to facilitate the human life. 


\section{Materials and Method}

A study of the fertilizer utilization management was conducted involving the traditional-market-waste liquid organic fertilizer and Setaria grass. The study used Completely Randomized Design, consisted of 6 (six) treatments and 4 (four) replicates in each treatment. The treatments were the applications of traditional market waste liquid organic fertilizer that was mixed with water of various concentrations (Table 1).

Table 1. The doses of liquid organic fertilizer of the treatments.

\begin{tabular}{|c|c|c|c|c|c|c|}
\hline \multirow{2}{*}{ No } & \multirow{2}{*}{$\begin{array}{c}\text { Teatment } \\
\text { Code }\end{array}$} & $\begin{array}{c}\text { Liquid } \\
\text { Organic } \\
\text { Fertilizer }\end{array}$ & Water & Total & $\begin{array}{c}\text { Width of } \\
\text { land } \\
\text { being } \\
\text { fertilized }\end{array}$ & $\begin{array}{c}\text { Volume of } \\
\text { Fertilizer/ } \\
\mathbf{m}^{2}\end{array}$ \\
\cline { 3 - 7 } & \multicolumn{3}{|c|}{ Liter } & $\mathbf{m}^{2}$ & ml \\
\hline 1 & S-0 & 0 & 0 & 0 & 100 & 0 \\
\hline 2 & S-1 & 10 & 10 & 20 & 100 & 200 \\
\hline 3 & S-2 & 10 & 20 & 30 & 100 & 300 \\
\hline 4 & S-3 & 10 & 30 & 40 & 100 & 400 \\
\hline 5 & S-4 & 10 & 40 & 50 & 100 & 500 \\
\hline 6 & S-5 & 10 & 50 & 60 & 100 & 600 \\
\hline
\end{tabular}

The results of laboratory analyses showed that the fertilizer contained nitrogen as much as 0.038 percent, $\mathrm{P}_{2} \mathrm{O}_{5} 81.748 \mathrm{mg} / 1, \mathrm{~K}_{2} \mathrm{O} 0.134$ percent and $\mathrm{C} / \mathrm{N}=0.92$. The size of each plot was $3 \mathrm{~m}^{2}$. The variables that were observed at the plant age of 50 days were the phenomena of plant growth included the height, the numbers of tillers and leaves, and the width of canopy. Chronologically, work procedures included land processing, cultivation, fertilization, plant management, and harvest. When the age of Setaria was 2 weeks, the plants were fertilized using liquid organic fertilizer with the doses as written in table 1, by spraying the fertilizer onto the soil surface. The data were analyses using analysis of variances, continued by using the Orthogonal Polynomial, and regression analysis for the doses of fertilizer.

\section{Results and Discussion}

\subsection{The conditions of experimental site}

The study was conducted at a field without tree canopy. The results of soil laboratory analysis showed that the soil content of Nitrogen was 49.35 ppm (very high), available $\mathrm{P}_{2} \mathrm{O}_{5}$ was 0.198 ppm (very low) and available $\mathrm{K}_{2} \mathrm{O}$ was 0.496 percent (fair). The texture class was sandy loam, containing sand fraction as much as 24.63 $\%$, dust fraction of $9.15 \%$ and clay of $66.22 \%$, with a soil pH of 5.11 (The Laboratory of Soil Science, Faculty of Agriculture, Jenderal Soedirman University, Indonesia)

On the basis of $\mathrm{pH}$, the soil was acidic [6], however, on the basis of its mineral contents, especially its high $\mathrm{N}$ content, the soil fairly support the growth of grasses. According to Huang et al., nitrogen is a macro mineral that highly required by plants [7]. Related to the above condition, according to Thomas and Schultze-Kraft the land in this study is capable of supporting the growth of certain plants, including grasses [8]. Aminudin and Hendarto report, Setaria (Setaria splendida) grass is able to grow under heavy condition of soils, therefore, better soil condition gave a more beneficial information of the study, especially in relation with the fertilization management [9].

\subsection{The heights of Setaria grass}

The results of the applied traditional market waste liquid organic fertilizer onto the Setaria (Setaria splendida) was showed in Table 2. The phenomenon of growth in term of height, is an aspect that can be used to know the quality of growth of plants. The mean value of height of Setaria due to the fertilization treatments was $50.17 \mathrm{~cm}$, with a range of $45.93 \mathrm{~cm}-52.05 \mathrm{~cm}$. The results were in accordance with the genetic value of the grass, which indicated that the genetic aspect cannot be erased due to the environmental factors [9].

The control grass without fertilization showed the tallest growth, might be due to the very high soil content of N. Rahman et al., states, nitrogen functions to stimulate the whole of plant growth, including height [10].

Tabel 2. Effect of traditional-market-waste liquid organic fertilizer on the growth phenomena of Setaria grass

\begin{tabular}{|c|c|c|c|c|}
\hline Treatment & $\begin{array}{c}\text { Plant } \\
\text { Height } \\
\text { (cm) }\end{array}$ & $\begin{array}{l}\text { Number of } \\
\text { tillers }\end{array}$ & $\begin{array}{l}\text { Number of } \\
\text { Leaves } \\
\text { (sheet) }\end{array}$ & $\begin{array}{c}\text { Canopy } \\
\left(\mathrm{cm}^{2}\right)\end{array}$ \\
\hline S-0 & $52.05^{\text {a) }}$ & $11.98^{\mathrm{b})}$ & $72.00^{\mathrm{c})}$ & $40.85^{\mathrm{d})}$ \\
\hline S-1 & $52.58^{\text {a) }}$ & $11.75^{\mathrm{b})}$ & $64.00^{c)}$ & $40.68^{\mathrm{d})}$ \\
\hline S-2 & $52.00^{\text {a) }}$ & $10.98^{b)}$ & $70.40^{c)}$ & $40.05^{\mathrm{d})}$ \\
\hline S-3 & $51.65^{\text {a) }}$ & $10.40^{\mathrm{b})}$ & $64.15^{c)}$ & $40.18^{d)}$ \\
\hline S-4 & $48.75^{\text {a) }}$ & $10.73^{b)}$ & $63.58^{\mathrm{c})}$ & $38.10^{\mathrm{d})}$ \\
\hline $\mathrm{S}-5$ & $45.93^{\text {a) }}$ & $10.38^{b)}$ & $56.85^{c)}$ & $37.83^{\mathrm{d})}$ \\
\hline $\begin{array}{l}\text { Mean } \\
\text { Value }\end{array}$ & 50.16 & 11.04 & 65.18 & 39.58 \\
\hline
\end{tabular}

Note : Similar superscripts in th samme collumns showed similar value $(\mathrm{P}>0.05)$

The usage of liquid fertilizer according to Budiraharjo et al., in an effort to utilize organic wastes has a potent to be applied in the fields [11]. According to Marpaung et al., the differences between traditionalmarket-waste organic compost to that of liquid is, the minerals from the compost need time space in order the minerals to be available to plants, on the contrary, those of liquid fertilizer, the minerals are available as soon as the fertilizer is applied to the soil [12]. It is reported by Hanolo that the decomposition process of compost causes the late availability of its minerals [13]. It is added by Hendarto at the time the minerals in the compost is available to the plants, the plants have arrived to their generative stage of growth that does not need minerals in excessive amount [14]. It is possible that minerals from the decomposition process of compost will be used for the next growth, namely after harvesting of the current grass. The results of this study were in line with those of Marpaung et al., (2014), that at the soil with high $\mathrm{N}$ content, the addition of $\mathrm{N}$ into the soil gave no significant effect on the height of plants. Wachjar 
and Kadarisman also report that the applications of various levels of liquid organic fertilizer gave no significant effect on the height of cocoa plants [15].

The results of analysis of variances showed tha there was no significant effect $(\mathrm{P}>0.05)$ of liquid organic fertilizer on the heights of Setaria grass, which indicated that the heights of the grass that received different concentrations of the fertilizer were relatively similar. However, the doses of the water showed a linear regression, $\mathrm{Y}=55.71-0.2218 \mathrm{X}$ (Figure 1), which indicated that higher concentrations of water in the fertilizer resulted in lower heights of plants, might be to the lower content of $\mathrm{N}$ in the mixtures.

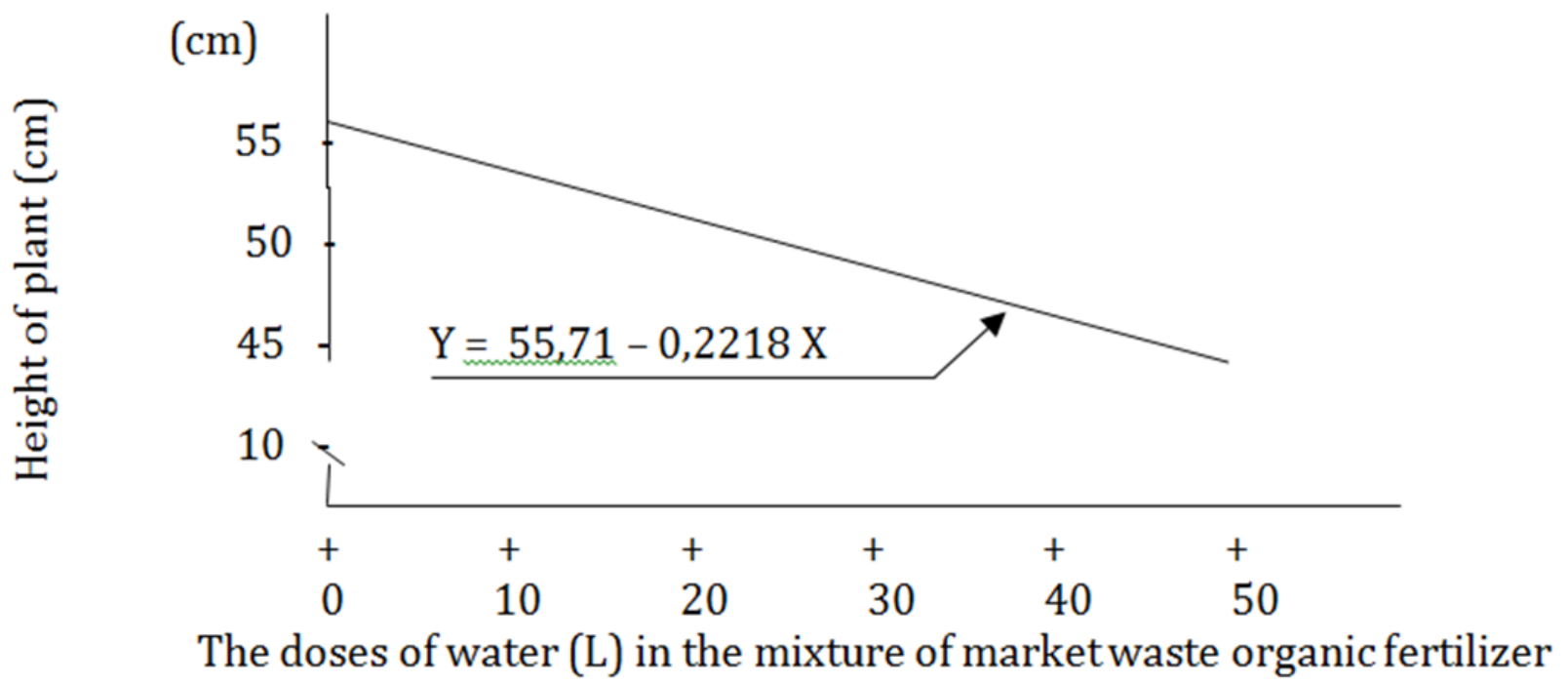

Fig. 1. Relationship between water mixture in the market waste organic fertilizer with the mean heights of Setaria Grass

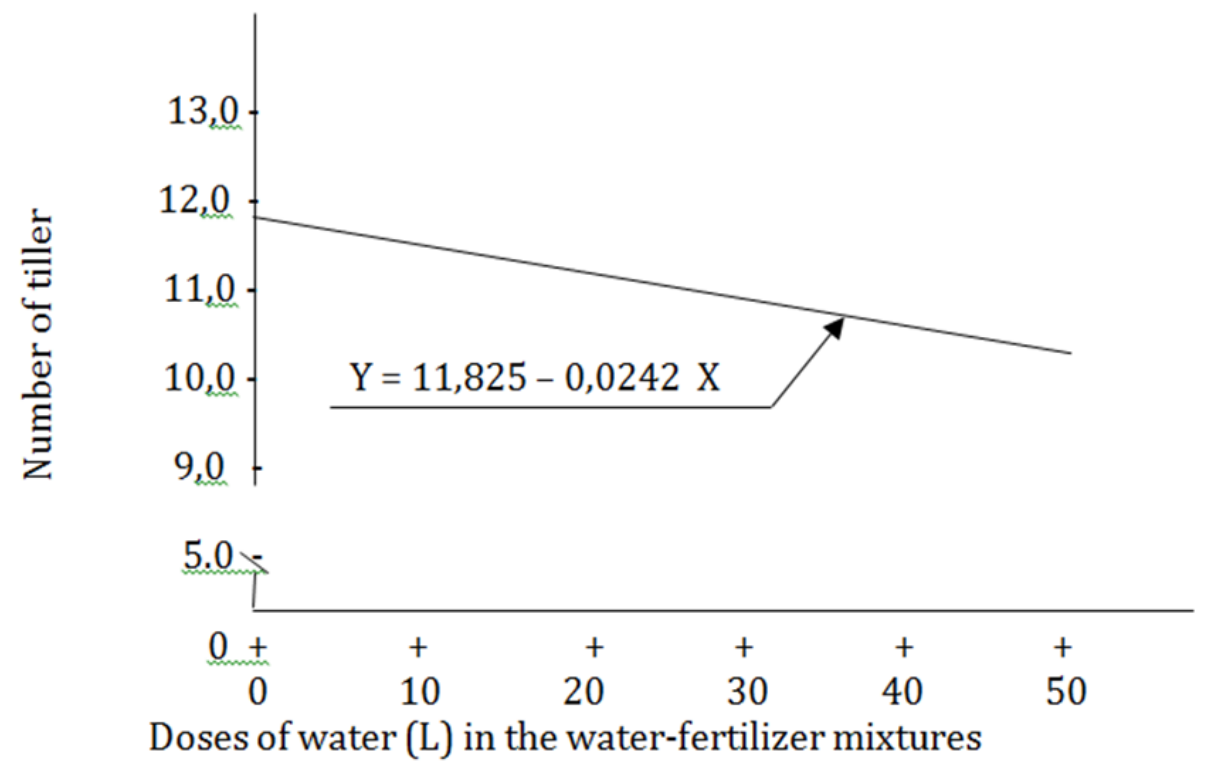

Fig. 2. Relationshi between water dosen in the market-waste lizuid organic fertilizer mixtures with the number of tillers of Setaria grass

Figure 1 showed, the higher the dilution of the marketwaste liquid organic fertilizer with water, the lower the height of Setaria grass. Although the anova showed a uniform results, the doses of water showed a linear response, therefore, the conclusion is, the less dilution of the fertilizer with water resulted in a higher height of
Setaria (Setaria splendida). It is possible that the ratio of water to fertilizer of 3 to 1 still resulted in a good condition. 


\subsection{The number of tillers of Setaria}

The productions of forage plants are greatly affected by the number of tillers. In general, the higher the number of tillers, the higher the production and the number of animal units that can be fed by the forage. The marketwaste liquid organic fertilizer is a natural resources as a product of human activity, represented an added value of the disposed wastes. Basically, all kinds of wastes have utility and economic values for human being, including the utility of wastes as a liquid fertilizer, finally, as a stimulant for livestock performances. The forage is a whole, accumulative products of all parts of forage plants, the number of tillers in the management of grass agronomy has a pivot role viewed from the production function. The higher the number, the higher the production [16].

The mean value of the number of tillers as a phenomenon of growth of Setaria grass was 11.04/ bunch of plant (Table 2) with a range of $10.38-11.98$ tillers / bunch. Higher doses of water in the mixture of water-fertilizer decreased the number of tillers. The fact was in line with the statement of Setiyowati et al., that the concentrations of minerals in the fertilizer determine the growth aspects of plants [17].

The analysis of variances and differences test showed, there was no significant differences $(\mathrm{P}>0.05)$ among the treatments on the numbers of tillers. However, the doses of water in the water-fertilizer mixtures resulted in a significant, linear relationship $(\mathrm{P}<$ $0.05), \mathrm{Y}=11.825-0.0242 \mathrm{X}$ in term of the numbers of tiollers of Setaria grass (figure 2). Table 1 showed that Setaria garss (Setaria splendida) without fertilization had the greatest number of tillers compared to those fertilized with market-waste liquid organic ferilizer. Greater volumes of water in the mixtures resulted in vewer numbers of tillers.

Figure 2 showed, the all 5 doses of water resulted in the decrease of the number of tillers of Setaria (Setaria splendida). This was in line with the repost, the decrease in mineral concentrations in the mixtures of waterfertilizer due to dilutions resulted in the decrease of plant growth, including the numbers of tillers.

These results were in accordance with the height of plant, the greater the doses of water in the waterfertilizer mixtures, the fewer the height and the numbers of tillers. Although the anova showed no significant effects of treatments on the number of tillers, however, the linear response of the doses of water on the number of tillers concludes that higher concentrations of fertilizer in the water-fertilizer mixtures resulted in the greater number of tillers of Setaria grass (Setaria splendida). Table 1 indicated, the water doses until up to 3 (three) times as those of the fertilizer still resulted in a fairly good growth condition.

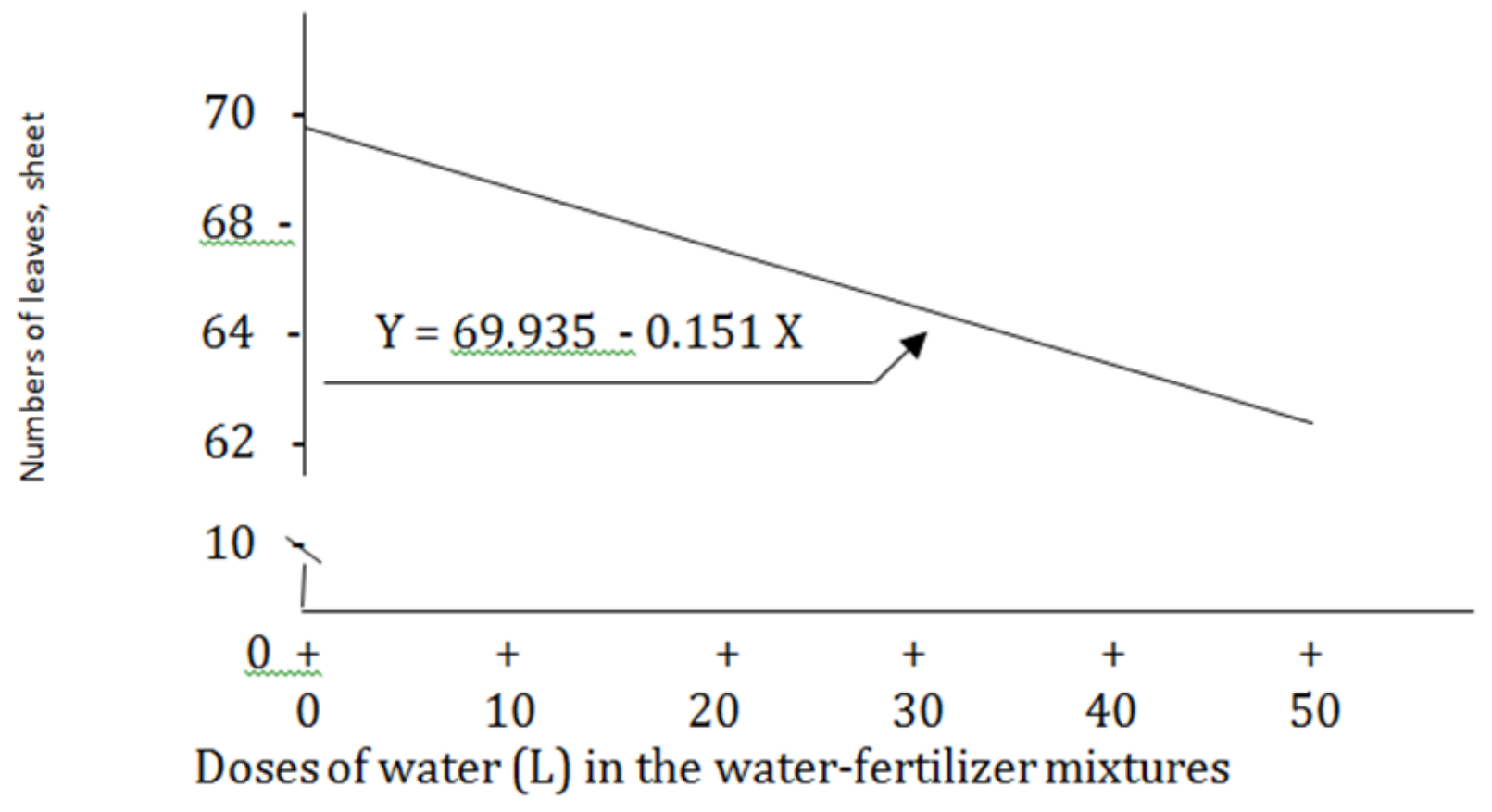

Fig. 3. Relationship between the doses of water in the water-fertilizer mixtures with the numbers of leaves of Setaria grass

\subsection{Numbers of leaves of Setaria}

The performances of production and quality of forage are greatly affected by leaf condition [18]. The productions of forage plants are expressed after harvest, one of which is represented by leaf as one of the production components [19]. Each addition of a leaf increases fresh matter weight. According to Hendarto farmers prefer leaf parts of forages plants rather than stems, because they are preferred by livestocks more 
than stems in order to enhance the livestock performances [4].

The mean of the numbers of leaves per bunch of Setaria (Setaria splendida) at the first defoliation were 65.16 sheets with a range of $56.85-72.00$ sheets (Table 2 ). The bunches without fertilization had the greatest numbers of leaves, with a mean of 72.00 sheets of leaves. Whereas for the fertilized bunches of plants, there were various mean values of the numbers of leaves, with a tendency that the greater volumes of water in the water-fertilizer mixtures resulted in a lower numbers of leaves. This was in line with the results of Abdullah et al., study that liquid organic fertilizer that was applied to indigofera showed a decreasing numbers of leaves due to the lower concentrations of minerals in the mixtures of water-fertilizer [20]. It was added that the leaves represent an important biomass in the productions of forage plants, because leaves are the vegetative parts of plants that have the highest quality of plant products. Taufika added that the taller plants generally have a greater number of leaves [3].

The results of anova showed that the treatments had no significant effect $(\mathrm{P}>0.05)$, however, the doses of water affected significantly $(\mathrm{P}<0.05)$ on the number of leaves of Setaria (Setaria splendida) as expressed by a linear equation, $\mathrm{Y}=69.935-0.151 \mathrm{X}$ (Figure 3 ). The figure showed that each dose of water addition resulted in a decrease of the number of leaves up to the 5 times as much water relative to the volume of the liquid organic fertilizer.

Other observations also showed that greater volumes of water in the water-fertilizer mixtures resulted in lower numbers of leaves. The response of figure 3 showed that higher concentrations of liquid organic fertilizer increase the number of leaves of Setaria grass (Setaria splendida). According to Setiyowati et al., and Rizqiani etal., liquid organic fertilizer can be used to fertilize all species of plants because it contains 13 kinds of macro and micro minerals that are absolutely required for the growths of plants; at the proper concentration, it is able to improve the quality of plants, including the number of leaves $[17,21]$.

\subsection{Canopy of Setaria}

Canopy may represents the vigority of plants to grow, that is needed to optimize the growth of plnats in order to achieve high level of production. The results of this study (Table 2) showed tha the mean value of canopy of Setaria (Setaria splendida) that was fertilized with market-waste liquid organic fertilizer was $39.58 \mathrm{~cm}^{2}$ at a range of $37.83-40.85 \mathrm{~cm}^{2}$ which indicated that the plant was uniformly and vigorously grew vertically high in all the treatments. The area of field that was exposed to sunlight supported the fact. Huang, et al., reported similar facts that the addition of $\mathrm{N}$ from the marketwaste liquid organic fertilizer resulted in a higher chlorophyl concentrations in leaves which in turn, promote photosynthesis and canopy formation [7]. It was added by Marpaung et al., that liquid organic fertilizer is bale to increase the vigority of plants, as ar esult, the plants become strong and the leaf canopy becomes wider [12].

In relation with the use of liquid fertilizer on the plants, it is possible that the use of fertilization techniques via leaves according to Rahmi and Jumiati, will reap better growth to increase the production of plants through the functions of stomata of plants. The canopy as a result, grows wider due to the application of the liquid organic fertilizer [22].

The anova showed that the treatments and the doses of water in the water-fertilizer mixtures did not give any effect $(\mathrm{P}>0.05)$ on the width of canopy of Setaria (Setaria splendida), which indicated that the widths of canopies of the treated and untreated plants were similar. This result was in accordance with that of Parman study, the uses of several concentrations of liquid organic fertilizer on potato plants did not give any differences on the parameters of growth [23]. However, the additions of water doses up to 5 times the volumes of fertilizer tended to produce shorter canopy. Table 2 , indicated that the additions of water volumes up to 3 times the volume of fertilizer showed fairly good growths.

The traditional-market-waste liquid organic fertilizer is abundant natural resources. Although the waste is one of the urban pollutants as the results of human activities, however, it is basically very useful for human life through its support to plant growth. The enter of liquid fertilizer into the agronomy management of plant will increase the diversification of businesses that have economy values and develop socio-cultural aspects in the life of human race.

\section{Conclusions}

On the basis of the discussion, the conclusion is, traditional-market-waste liquid organic fertilizer plus water as much as 3 times the volume of the fertilizer can be used to support the growth of Setaria (Setaria splendida) in order to increase the performances of ruminant animals.

\section{References}

1. E. Hendarto, Dimensi Lingkungan Tata Ruang Peternakan Sapi Perah Rakyat Di Kabupaten Banyumas, Provinsi Jawa Tengah. Disertasi. Program Pascasarjana. Universtas Diponegoro. Semarang. (2011)

2. H. Greatheat, Proceedings of the nutrition Society. 62: 279-290 (2003)

3. R. Taufika, Jurnal Tanaman Hortikultura. 8 (2): 110 (2011)

4. E. Hendarto, E. Widyastuti, D.R. Puspita, A. Iqbal, E. Hilmi, Muslihudin, E. Dewanto, A. Anwar, E.B. Riyanto and S.A. Amir, Analisis Permasalahan Lingkungan Di Daerah dan Solusi yang Dapat Dikembangkan. Pusat Penelitian Lingkungan Hidup, Lembaga Penelitian dan Pengabdian 
Kepada Masyarakat, Universitas Jenderal Soedirman. Purwokerto. (2011)

5. E. Hendarto, Pengaruh Kombinasi Pupuk Organik dan Taraf Urea terhadap Kualitas Visual dan Produksi Rumput Raja (Pennisetum purphoides). Jurnal Pembangunan Pedesaan. Lembaga Penelitian Universitas Jenderal Soedirman. Purwokerto. (2005)

6. J.F.S. Ferreira, M.V. Cornacchione, X. Liu and D.L. Suarez, Nutritient Composition, Forage Parameters, Journal Agriculture. 5: 577-597 (2015)

7. Z.A. Huang, D.A. Jiang, Y. Yang, Y.W. Sun and S.H. Jin. Photosynthetica. 42 (3): 357-364 (2004)

8. D. Thomas, and R. Schultze-Kraft, Tropical Grassland. 24:87-92 (1990)

9. S Aminudin, dan E. Hendarto. Buku Ajar Agrostologi. Fakultas Peternakan. Universitas Jenderal Soedirman. Purwokerto (2000)

10. Rahman, D. Lasamadi, S.S. Malalantang and Rustandi, Jurnal Zootek (2012)

11. K. Budiraharjo, M. Handayani and G. Sanyoto, Jurnal Ilmu-ilmu Pertanian, Mediagro. 7 (1): 1-9 (2011)

12. A. E. Marpaung, B. Karo and R. Tarigan, Journal Horticultura. 24 (1): 49 - 55 (2014)

13. W. Hanolo, Jurnal Agrotropika 1 (1): 25 - 29 (1997)

14. E. Hendarto, Penampilan Aspek Agronomi Rumput Gajah (Pennisetum Purpureum) Di Bawah
Pengaruh Berbagai Jenis Dan Dosis Pupuk Organik Dan Anorganik. Prosiding Seminar Nasional Peran Pertanian Dalam Menunjang Ketahanan Pangan dan Energi Untuk Memperkuat Ekonomi Nasional Berbasis Sumberdaya Lokal. Fakultas Pertanian. Universitas Jenderal Soedirman. Purwokerto. (2012)

15. A. Wachjar, and L. Kadarisman. Buletin Agronomi. 35 (3): 212 -216 (2007)

16. E. Hendarto, dan Suwarno, Bionatura. Journal of Life and Physical Sciences. 15 (2): 86 -91 (2013)

17. Setiyowati, S. Haryanti and R.B. Hastuti, Bioma. 12 (2): 44-48 (2010)

18. S. Tudsri, S.T. Jorgensen, P. Riddach and A. Pookpakdi, Tropical Grasslands. 36: 248 - 252 (2002)

19. I. Herdiawan, L. Abdullah, D. Sopandi, P.D.M.H. Karti and N. Hidayati. Journal Animal and Veteriner Science. 17 (2): 276 -283 (2012)

20. Abdullah, L. D.D.S. Budhie and A.D. Lubis, Pastura. 1(1): $5-8$ (2011)

21. N.F. Rizqiani, E. Ambarwati, and N. W. Yuwono, Jurnal Ilmu Tanah dan Lingkungan. 7 (1): 43 - 53 (2007)

22. A. Rahmi, and Jumiati, Agritrop. 26 (3): $105-109$ (2007)

23. S. Parman, Buletin Anatomi dan Fisiologi. 15 (2):21-31 (2007) 